\title{
Hedge Funds and their (Non)regulation ${ }^{\#}$
}

\author{
Petr MUSÍLEK
}

Institutional investors count among significant participants on global capital markets. These investors are however not a homogeneous group, since they not only use different investment policy, but operate also in different regulatory and tax environment. The objective of this contribution is to analyze the impact of institutional investors on capital markets, while special attention will be paid to the segment of hedge funds, both, in the period before the outbreak of global financial crisis and in the post-crisis period, as exemplified by the USA and the European Union.

\section{Institutional investors and their impact on capital markets}

Hedge funds may be classified as institutional investors playing considerable role in financial systems. What do we understand under the term "institutional investor"? According to Gitman and Joehnk (1990, p. 10), institutional investors are “... professionals paid for management of other people's money. They are employees of financial institutions such as banks, life insurance companies, mutual funds, pension funds, large non-financial corporations, and in some cases also individuals ...". For the purpose of this contribution, we determine the institutional investor as an institution managing investment assets of great extent, while using professional investment methods. Following institutions are classified as institutional investors: open and closed funds of collective investment, banks, pension funds, insurance companies, hedge funds, and other managers of private portfolios.

The ever-increasing significance of institutional investors on capital markets is evoked by several factors, and deregulation of financial systems in the eighties and nineties of the last century and at the beginning of the new millennium prior to the outbreak of global financial

\# This paper is elaborated within the project of Czech Science Foundation P402/10/0289 Non-stability of financial markets and efficiency of their regulation.

Prof. Ing. Petr Musílek, Ph.D. - Vice Dean for Science, Professor; Faculty of Finance and Accounting, University of Economics Prague, W. Churchill sq. 4, 13067 Prague, Czech Republic; < musilek@vse.cz>. 
crisis ranks among the most important. Not only in consequence of massive competition increase in the area of commercial banking, but also as a market response to implementation of the Basel model of banking regulation that required considerable increase of shareholders' equity, bank institutions expanded into assets management, which is analyzed in details by Revenda (2011). Also liberalization of the investment environment contributed to the boom of institutional investment, both, in the area of generating and distribution of investment and pension products and also in possibilities to allocate investment assets. Another factor of institutional investors' expansion is a demographic development that is specific by constant aging of population in developed countries, which becomes evident in huge demand for investment-insurance products that provide income to persons in retirement age. And finally, technological revolution in the area of computer and telecommunication technology opened wide opportunities to institutional investors in the liberalized investment environment. Technical progress contributed to definite drop of transaction and management costs related to professional asset management.

Increased importance of institutional investors influences significantly the microstructure of capital markets. Liquidity of secondary capital markets, adequate standards of information disclosure, market oriented accounting, functional legislative environment, and healthy banking system are extremely important for activities of institutional investors. Liquidity requirements of institutional investors support probably not only consolidation of fragmented national stock exchanges into multinational stock electronic trading systems, but also contribute to creating specialized institutional markets. Institutional investors influence significantly also the structure of demand for investment instruments. As compared with individual investors, institutional investors in principle invest in long-term and foreign investment instruments. It seems that also the development of financial engineering is stimulated by institutional investors who permanently require new products to control investment risks, tax positions, and compliance or evasion of regulatory rules, which is analyzed in details by Dvořák (2006). Institutional investors also positively contribute to formation of the global capital market through international investment development. With respect to the fact that national capital markets were not positively correlated perfectly in the past, it was possible to diversify the systematic risk based on international investments. Precisely the effort to diversify the systematic risk became progressively evident by extensive multi-nationalization of portfolios of 
institutional investors, which was however the cause of price integration of individual national capital markets into a global market at the beginning of the new millennium. Institutional investors also positively contribute to stimulation of the offer of the risk capital. In particular American institutional investors allocate part of their portfolios in young and fast-growing companies, which was one of the factors supporting the dynamic economic growth from the second half of the eighties of the last century practically to the outbreak of global financial crisis in 2008. We must also not ignore the fact that institutional investors manage companies based on the pressure applied to the management by maximizing performance of stock instruments of publicly tradable companies. In the nineties of the last century, some institutional investors and their asset managers switched gradually from passive to active execution of ownership rights, which contributed positively not only to the growing value of stocks, but also to increased efficiency of joint-stock companies.

Reasonable price volatility of investment instruments is a common part of the investment process. Financial economists however examine particularly the impact of excessive or even extreme price volatility of investment instruments on stability of financial systems. Are institutional investors the cause of turbulences on the global capital market, or do they on the contrary rather contribute to its higher stability by their activities? Empirical studies carried out to date (e.g. Sias, 1996, Kirkpatrick, 2009, or Claessens, Ariccia, Igan, and Laeven, 2010) rather confirm the opinions that consolidation of investment assets under management of large institutional investors may generate excessive price volatility of investment instruments. Portfolio managers are namely often vulnerable to "herd" behavior, since their performance is usually judged to the market benchmark set, which then proves in imitating investment strategies of crucial investment players on capital markets. Institutional investors also sometimes respond to unexpected information influencing prices in similar manner, which in aggregate expression causes particularly significant fluctuation of net demand for insufficiently liquid investment instruments.

It is evident that institutional investors use also standardized systems of risk management. The core of these systems consists in statisticalmathematical models with very similar and preset parameters, which in case of both, positive and negative price shock outbreak, leads to "herd" responses of institutional investors. In particular globally operating commercial banks started expanding to investment markets relatively on a 
massive scale. Banking houses at the same time developed a new banking discipline in connection with the development of mathematical financial economy and computer technology - the so-called modern risk management. In 1994, the Value-at-Risk (VaR) approach was used in banking for risk management for the first time by American group JPMorgan Chase. VaR measures what loss may be realized due to modification of monitored risks (interest rate, exchange rate, stock, or commodity) in a certain period with predefined probability. The use of VaR approach started massively prior to the outbreak of global financial crisis also in the area of asset management, not only due to its simple application, but mainly because this approach was intelligible and easily understandable to top managers and members of statutory bodies. VaR approach was not only recommended, but also even often required by regulatory and supervisory authorities. This approach has however several fundamental (and difficult to remove) deficiencies, the most serious of which are:

- VaR does not express what are the highest losses that may be achieved from investment instruments or investment portfolio, and significantly underestimate probability of occurrence of an extreme price-forming shock,

- VaR neglects the systemic risks,

- most VaR methods are based on presumption of normal distribution of returns from investment instruments,

- VaR approach supports pro-cyclic behavior of capital markets, since most VaR users operate with similar input data (indeed with historical time series of returns/losses of investment instruments or portfolios) and characteristics of models, which necessarily bring out "herd" behavior of banks and managers of investment portfolios and escalates the financial panic even further,

- VaR is in principle based on the presumption of previous development repetition (though with certain modifications) in the future period, which is however rather a coincidence than reality, since there are no rational grounds for repeating of unexpected fundamentally-psychological significant price-forming events that change the behavior of return rates of investment instruments or portfolios,

- in the period prior to the outbreak of global financial crisis, credibility risk and the risk of loss of liquidity were absolutely neglected in applying the VaR method. 
Extensive and usually mechanical use of VaR method (though in some cases supplemented with stress testing and analysis of different scenarios) confirmed mainly managers of banking houses in their belief that they may invest on capital markets in volatile instruments using substantial financial leverage, since they are capable to manage risks effectively based on the so-called modern risk management approach, and no considerable threat is imminent. This hazardously oriented strategy was successful in certain banks (e.g. American, British, Dutch, or Icelandic) for relatively long time, and some managers managed to increase profitability unprecedentedly and thus transform the bank stocks from previously conservative titles into titles of the growth type (growth stocks). We however believe that it was not due to applying the so-called modern risk management, but mainly due to unusually long (practically from the mid-eighties of the last century to the middle of 2008) favorable development on global investment markets. After shifting the investment mood, many banks did not manage to change their investment strategy on time and got into serious problems.

We cannot even rule out that institutional investors may also behave in irrational manner, since their investment strategies are not supported with adequate fundamental factors. In particular the newly formed investment markets, young companies, and investment innovations often suffer from information asymmetry. Institutional investors and asset managers then in conceiving and realization of their investment strategies proceed rather from assumptions and investment feelings than from true and accurate fundamental information, which results in investment mistakes that are usually positively correlated. Its consequence is economically unfounded demand for certain investment instruments and subsequent price bubble.

\section{Special type of institutional investors: hedge funds}

Traditional hedge funds do not represent ordinary institutions of collective investment, but they have the nature of private and nonregulated investment products intended for selected clients. For economic, tax, and regulatory-supervisory reasons, hedge funds operate in particular in the USA and off-shore centers, and relatively small number in the European Union. Clients of hedge funds consist exclusively of rich or professional investors and their number usually does not exceed several tens or hundreds, which means that hedge fund securities have the nature 
of private investment instruments. Managers of hedge funds use flexible approach to portfolio management, because they are not subject to any regulation and assets allocation and diversification regulations. They invest in wide range of investment instruments (e.g. stocks, bonds, financial derivatives, or commodities) using active investment techniques including leverage (encumbered) investment operations. Managers of hedge funds are remunerated using both, fixed method (manager's commission usually 1-2\% p.a. of the value of managed assets, supposing however that the portfolio manager achieves positive returns) and based on performance of the managed portfolio (usually $20 \%$ of annual returns achieved). It is usually required at the same time that the portfolio manager becomes a partner of the investment structure and invests also his/her own funds in the hedge fund's portfolio. Investors cannot withdraw invested funds from the hedge fund immediately, but they must observe the notice period, which is between 30 days and 3 years. This notice period is sometimes also supplemented with considerable sanction withdrawal charges.

Hedge funds may not be mixed with other types of non-regulated investment structures. Hedge funds are very often similar to private equity funds, not only by the method of capital collection, but also by the system of managers' remuneration. Great difference however consists in the investment method. Hedge funds invest mainly to liquid investment instruments, which enables investors to withdraw from fund structures. On the contrary, private equity funds invest large portion of assets in nonliquid investment instruments, which means that fund investors have practically no chance to withdraw before the predefined horizon of realized investment policy. Venture capital funds invest assets in private nontradable companies through important capital participation for a relatively long investment period. Venture capital funds search for highly speculative investment opportunities. Therefore their instruments rank among considerably hazardous and practically non-liquid investment assets.

Hedge funds were originated on the American market at the end of forties of the last century. In 1949, Jones Hedge Fund was founded that used hedge transactions with stocks, based on combination of margin trading and short selling. Profits were achieved through the selection of undervalued stock titles for margin trading and overvalued instruments for short sales. In following two decades, more than 150 hedge funds were founded on the American market. Some of them however progressively abandoned basic hedge principles and used increasingly borrowed funds. Upon the drop of share prices in the second half of the sixties of the last 
century, most of them suffered great losses and essential part of them also terminated their business activities. The follow-up renaissance of hedge funds was experienced in the mid-nineties of the last century, not only due to liberalization of international investments, but also due to wide supply of new investment opportunities. Newly founded hedge funds in last two decades started using various investment strategies, which enables to differentiate macro funds (they enter into positions of changing global economic conditions that show in stock prices, interest rates, or exchange rates), global funds (they invest on selected developed and emerging stock markets), market-neutral funds (they use hedging operations consisting in combination of margin trading and short selling), sectorial funds (they invest in selected sectorial stock only), short sales funds (they realize mainly short sales and thus speculate in price fall of investment instruments), event-driven funds (they search for specific events such as acquisitions or mergers, cause significant fluctuations in market prices of stock instruments), and funds of funds (they invest in other hedge funds, using borrowed funds). Macro funds, global funds, event-driven funds, and in recent years also short sales funds became the most widespread. At the end of the nineties of the last century, more than 5000 hedge funds existed on global investment markets, and they managed almost USD 300 bil. The volume of assets managed by hedge funds was constantly increasing in the new millennium and exceeded USD 2.5 trillion before the outbreak of global financial crisis. In the course of the global financial crisis, many hedge funds suffer great losses and withdrawal of clients; the volume of assets managed dropped approximately to one half, and hundreds of funds had to terminate their operation. With gradual overcoming of the results of global financial crisis, certain stabilization was experienced in the segment of hedge funds. Substantial characteristics of the sector of hedge funds are demonstrated by the following table.

Tab. 1: Characteristics of hedge funds (HF) sector (world, 1990-2011)

\begin{tabular}{|c|c|c|c|c|c|c|}
\hline Item & 1990 & 1995 & 1997 & 2007 & 2009 & 2011 \\
\hline Number of funds & 1977 & 4700 & 5500 & 10000 & 8000 & 7000 \\
\hline HF assets in bil. of USD & 67 & 217 & 295 & 2500 & 1542 & 2040 \\
\hline $\begin{array}{l}\text { Inst. investors' assets in } \\
\text { bil. of USD }\end{array}$ & 13506 & 23079 & 28407 & 40300 & 34000 & 38000 \\
\hline HF share in \% & 0.50 & 0.94 & 1.04 & 6.20 & 4.53 & 5.37 \\
\hline
\end{tabular}

Source: Barclay Hedge (2012), TheCityUK (2012), OECD (2012) 


\section{Post-crisis regulation of hedge funds}

It results from the review above that hedge funds did not play very great role on global investment markets at the beginning of the nineties of the last century. Their importance however increased significantly in the new millennium. In addition, hedge funds started using extensively also leverage products and some of them took a fancy of high-frequency trading, which multiplied their position on global investment markets. As already mentioned, part of hedge funds also operates from off-shore centres (in particular from Cayman Islands) where regulatory and supervisory is almost non-functional. Even before the first outbreak of global financial crisis, financial research started bringing clear evidence that hedge funds may contribute to financial instability, mainly thanks to the aggressive investment strategy used (e.g. Fung and Hsieh, 2000), "herd" behaviour (e.g. Brunnermeier and Nagel, 2004), excessive indebtedness (e.g. Garbaravacius and Dierick, 2005), or credit risk occurrence of the counterparty (e.g. Cifuentes, Ferrucci, and Shin, 2005). In addition, non-transparency of the sector of hedge funds makes almost impossible to monitor the systemic risks of this specific investment sector. Not until the outbreak of global financial crisis, after several decades of operation of hedge funds as non-regulated investment structures, the segment of hedge funds began to be considered a nontransparent market that may deepen financial instability even by regulatory authorities. Washington summit of G-20 countries in autumn 2008 came to the conclusion that hedge funds may contribute to financial turbulences, therefore it is appropriate to monitor reasonably their investment activities, including the volume of their leverage positions. At the next summit in London (April 2009), G-20 representatives reached an agreement that hedge funds and their managers should not only be subjected to registration and information duty, but also to the obligation to implement functional system of risk management. Following the London summit, the International Organization of Securities Commissions (IOSCO), issued a document in June 2009, with general principles for regulation and supervision of funds that invest in hedge structures. Toronto summit of G-20 in June 2010 supported prompt implementation of transparent supervision of hedge industry, having integrated international nature of non-discriminatory character.

American mortgage crisis and fall of the leading investment bank Lehman Brothers opened necessarily the discussion on sweeping reform of the American financial system. Multi-factor nature of American financial 
crisis consists not only in deflation of the bubble of real-estate prices supported by excessive credit expansion, but also in extensive speculation of insufficiently capitalized financial institutions on non-transparent markets, inefficient operation of rating assessment market, spread of dishonest practices, and failure of the regulatory-supervisory mechanism. The Ministry of Finance of the USA therefore prepared a proposal of a sweeping financial reform that however underwent a stormy professional and law-makers' debate. The original proposal of financial reform underwent significant changes within the legislative process and transformed into a compromise version known as Dodd-Frank The Wall Street Reform and Consumer Protection Act, in short DFA (2010). As usual in the USA, this act also carries indication of key persons in the legislative process. The key role was played this time by $\mathrm{Ch}$. Dodd and B. Frank. The act became effective in July 2010, although some of its provisions have delayed legal force. The objective of DFA is to reduce progressively the risk exposure of large banks, not only by increasing the capital adequacy, implementing liquidity rules and leverage principle, but also by segregating the business department with certain derivatives from the main business operation of the bank to subsidiary companies.

As already mentioned, the importance of hedge funds in particular on American capital markets increased significantly in the new millennium. After the fall of Lehman Brothers, American hedge funds were considered not only a non-transparent segment, but also potential source of systemic risks that may be the cause of financial crisis. Therefore DFA includes an act in its clause four that regulates registration of investment managers of private funds (Private fund Investment Advisers Registration Act, 2010). This act amends the Investment Advisers Act from 1940 and revokes the greater part of previous exceptions from registration duty applied for several decades by managers of hedge funds and other private funds. Post-Lehman legislative regulation implements mandatory registration of hedge funds managers who are responsible for assets exceeding USD 150 mil., at the federal Securities and Exchange Commission. Managers of smaller hedge funds and other private funds (within USD 25 to 150 mil.) are also subject to registration, however not on the federal but national level. The new implemented registration system for managers of hedge funds and other private funds however still enables to use several exceptions that relate in particular to foreign private managers located outside the USA (with less than 15 private clients in the USA with investment assets not exceeding USD 25 mil.), managers of risk funds, and managers of family funds. New legislation also regulated the definition 
of an accredited investor, who may together with professional investors invest in hedge funds. The accredited investor is considered a physical entity with the minimum income USD 200 ths. in last two years (or USD 300 ths. with a spouse), with the assumption to maintain such income in the current year, or who owns net assets exceeding USD 1 mil., without major residential estate.

Not only registered but also non-registered managers of hedge funds and other private funds will have to also create information systems, in which they are obliged to keep data particularly on the volume of assets managed, amount of indebted positions, risk of counterparties, business and investment positions, types of investment assets, appraisal policy, and business practices that must be controlled by supervisory authorities on a regular basis. Supervisory authorities may also acquire other important and fundamental information from information systems of managers. Managers of hedge funds, registered at the federal Securities and Exchange Commission are obliged to create a position of a Chief Compliance Officer. This person is responsible not only for preparation of the regulation base in the "Compliance Manual" form (including most important policies of managers such as monitoring, marketing, claims, initial offerings, evidence, dishonest practices, portfolio management, appraisals, information duty or personal data protection), but also for observance of legal and internal regulations.

DFA also seeks to reduce connection of banks and hedge funds, based on application of Volcker's principle. This principle reduces banks' business activities at their own account and banks' investments in hedge funds and private funds up to maximum amount of $3 \%$ of the capital defined as Tier I. It is however modified version of the original Volcker's principle only, which was to forbid banks fully to deal with and invest to risky investment instruments at their own account. After heated professional debate, significantly lighter version of this principle was adopted. If hedge funds execute transactions with derivatives, then postcrisis approach to the derivate market will apply to them. It is in particular significant tightening of over-the-counter transactions with derivatives (mainly swap contracts). We may at the same time anticipate that not only the institute of central counterparty for most over-the-counter derivatives but also the duty to execute derivate transactions either on stock markets and/or on special swap markets will be implemented for financial institutions (including hedge funds) in the foreseeable future. The postcrisis model of regulation and supervision of managers of hedge funds 
may still be classified as a "light" regulatory approach, based mainly on almost overall implementation of registration duty of hedge fund managers and on the effort to reduce occurrence of information asymmetry in relation to investors and supervisory authorities. Managers of hedge funds and other private funds had a very short time to adapt to the new legislation, i.e. 12 months only. The problem however is that DFA and other new legal regulations are relatively general legal standards, and discretional power to create regulations is mostly transferred to supervisory authorities, which are in addition obliged to process tens of specialized studies and propose or adopt other regulation rules according to them. It is therefore very difficult to estimate the definite nature not only of the whole American financial reform but also of individual regulations for managers of hedge funds and other private funds.

Significant changes in the approach to the segment of hedge funds were experienced in the post-Lehman period also in the European Union, where these funds however do not play such great role in the financial system as in the USA, except for Great Britain. Global crisis uncovered some weak components also in the European financial system, and British hedge funds are just one of them. Although the operation of hedge funds was by no means the primary cause of the global (and also European) financial crisis, their non-transparent and often aggressive investment style complicated considerably not only identification of financial instability, but obstructed also in adopting effective recovery programs. Several years lasting discussion in various bodies of the EU on the regulation model of hedge-type business operation finally eventuated in accepting an extensive Alternative Investment Fund Managers Directive (AIFMD, 2011), that however does not cover hedge funds only, but also private equity funds, venture capital funds, trust structures, and all other funds operated in the EU that are not subject to regulation according to the Directive of the European Parliament and the Council No. 2009/65/EC, on coordination of legal and administrative regulations of collective investment in transferable securities (UCITS, 2009), as yet. Adopted Directive will significantly influence not only the operation of European funds, but also funds outside the Union that are offered to investors from the European Union.

The Directive implements the permission mechanism for managers of alternative funds who actively collect the capital from large number of investors and are not at the same time subjected to the regime according to the Directive UCITS. Lighter permission regime (drawn up on the 
national level) will apply to funds with the assets up to EUR 100 mil., or funds up to EUR 500 mil., if they do not used leverage products and the investors' right of resale is longer than 5 years. On the contrary, the new Directive will not apply to holding companies, joint ventures, pension funds, family funds, and securitization special-purpose units. Member states of the EU may permit offering of all or selected alternative investment funds even to non-professional investors, based on the appraisal whether the fund is suitable also for less experienced investor.

Obtaining licenses for managers of alternative funds is subject to quite strict requirements, and the applicant must present required information not only on the manager (top managers, identification of stockholders and associates of the manager with qualified participation, business plan, remuneration system), but also on individual alternative investment funds (status, investment strategy, depository). The precondition for obtaining the license to for alternative funds management effective in all member states of the EU is in particular the sufficient capital adequacy (EUR 125 ths.). If the value of assets of alternative investment funds however exceeds EUR 250 mil., the fund manager must increase the capital by $0.02 \%$ of the amount that exceeds EUR 250 mil., and the total of the initial and additional capital must not exceed EUR 10 mil. Another important precondition for obtaining the license of the manager of alternative funds is the sufficient and quality personnel.

Managers of alternative investment funds must act with professional care, impartially, and prevent potential conflicts of interest. They must in particular fulfill the information duty against supervisory authorities and investors (e.g. provide required information prior to execution of the investment decision, disclose annual reports, or report amounts of leverage positions). Managers of alternative investment funds are at the same time obliged to implement risk and liquidity management systems (identification and measuring of all risks including regular stress tests) that must be also functionally and hierarchically separated from operations and management activities. Managers must also define maximum leverage effect for each alternative investment fund and observe them. National supervisory authorities will even gain powers to define maximum amount of the leverage position, with the aim to reduce the systemic risks in the period of financial instability and thus minimize the risk of financial crisis occurrence. 
Managers of alternative investment funds will have to implement large number of external and internal control mechanisms. Each alternative investment fund will be subjected to control of an independent depository (bank or investment firm). Lighter regime will apply in case of alternative investment funds without resale right in first five years, private equity funds or risk funds, when depository's duties may be transferred to a notary public, attorney, registrar, and/or other subject. Managers must also implement the system of independent, regular, and impartial appraisal of assets in the portfolio of alternative investment funds, and such appraisal may be realized by external expert, depository, and/or own administrator, if sufficient organizational conditions providing a guarantee of fair appraisal of the assets alternative investment funds are created for this.

Fundamental change in the segment of hedge funds, in the fashion of banks, will consist in implementation of rules for remuneration of managers and top employees of alternative investment fund managers. The remuneration system must correspond with due and efficient risk management; and the most important principles are in particular:

- remuneration principles are in compliance with objectives of managers of alternative investment funds and their investors, and concurrently do not incite conflict of interests,

- independent regular (at least annual) controls of the remuneration system,

- definition of the balanced fixed/floating remuneration component ratio,

- evaluation of the results achieved is carried out in longer period and within the context of the whole investment cycle,

- considerable share payment, however at least $40 \%$ of the floating component, is made at the time that is reasonable with respect to the life cycle and principles of repurchase of respective alternative fund,

- definite payment of the floating component is only made under the condition of good financial situation of the manager and respective alternative investment funds.

Although the Directive on managers of alternative investment funds became effective in August 2011, its putting into the European investment practice will be quite a lengthy and complicated issue, since the transposition period for individual member states of the EU ends in August 2013 and market participants have then one more year to adapt to 
the requirements set. Considerable complication is however the fact that the Directive will be accompanied with a whole series of implementing regulations, the processing of which is currently only in progress. Even more lengthy issue will be to implement the Directive and other Union regulations in relation to hedge fund managers outside the Union whose transition period is practically till 2018 .

\section{Conclusion}

In the long-term point of view, institutional investors have very positive impact on capital markets, since they not only contribute by their extensive and frequent activities to higher liquidity of secondary markets and reduction of transaction cost, but also incite creation of modern trading systems. On the other hand, we cannot rule out that institutional investors may be liable under certain conditions to "herd" behavior, which may create seeds of future financial instability. The question however is whether regulatory-supervisory authorities (in particular financial stability committees) may identify the "herd" behavior of managers of institutional investors' portfolios on time and take adequate measures. Special type of institutional investors - hedge funds - for several decades operated in almost unregulated environment. Institutional response to global financial crisis influenced significantly the position of hedge fund managers who are newly subjected to regulatory-supervisory mechanism. The main objective of the new approach to hedge funds industry is not only to create conditions for financial stability (by central monitoring of the systemic risks resulting from portfolios of hedge funds and their leverage positions), but also to reduce information asymmetry by making the business and investment policy of hedge fund managers more transparent (keeping important records and their regular or random control). The new regulatory approach to hedge funds does by no means seek detail regulation of their investment policies by defining acceptable investment assets or various rules of risk diversification, which is on the contrary usual for regulation and supervision of collective or pension investment institutions. The American law regulating registration of investment managers of private funds had a very short implementation period and represents quite sensitive approach to the hedge industry. We cannot however say the same of the European Directive for managers of alternative investment funds. We believe that this Directive is too extensive, it implements nonunderstandably standard licensing of alternative fund managers (similar to investment companies operating in collective investment area), and its 
putting into investment practice is inadequately complicated and lengthy. We are afraid that this insensitive European model of regulation and supervision of alternative fund managers may negatively influence not only the competitive environment, but increase also unreasonably the management cost of hedge funds and other private funds.

\section{References}

[1] Barclay Hedge (2012): Hedge Funds. [on-line], Fairfield, Barclay Hedge c2012, [cited 22 ${ }^{\text {nd }}$ September, 2012],

$<$ http://www.barclayhedge.com/research/indices/ghs/mum/HF_Mone y_Under_Management.html $>$.

[2] Brunnermeier, M. - Nagel, S. (2004): Hedge Funds and Technology Bubble. Journal of Finance, 2004, vol. 59, no. 5, pp. 2013-2040.

[3] Cifuentes, R. G. - Ferruci, G. - Shin, H. S. (2005): Liquidity Risk and Contagion. Journal of the European Economic Association, 2005, vol. 3, no. 2-3, pp. 556-566.

[4] Claessens, S. - Ariccia, G. - Igan, D. - Laeven, L. (2010): Lessons and Policy Implications from the Global Financial Crises. [on-line], Washington, D.C., International Monetary Fund, Working paper no. 10/44, [cited 22 ${ }^{\text {nd }}$ September, 2012], <http://www.imf.org/external/pubs/ft/wp/2010/wp1044.pdf>.

[5] Dodd-Frank The Wall Street Reform and Consumer Protection Act (2010). [on-line], Washington, D. C. U. S. Congress, 2010, [cited $21^{\text {st }}$ July, 2010], <http://www.sec.gov/about/laws/wallstreetreform-cpa.pdf >.

[6] Dvořák, P. (2006): Finanční deriváty (Financial Derivatives). Praha, Oeconomica, 2006.

[7] Fung, F. - Hsieh, D. A. (2000): Performance Characteristics of Hedge Funds and Commodity Funds: Natural vs. Spurious Biases. Journal of Financial and Quantitative Analysis, 2000, vol. 35, no. 3, pp. 291-307.

[8] Garbaravicius, T. - Dierick, F. (2005): Hedge Funds and their Implications for Financial Stability. [on-line], Frankfurt am Main, European Central Bank, Occasional Paper no. 34, c2005, [cited 22 ${ }^{\text {nd }}$ September, 2012], <http://www.ecb.europa.eu/pub/pdf/scpops/ecbocp34.pdf $>$. 
Musílek, P.: Hedge Funds and their (Non)Regulation.

[9] Gitman, L. J. - Joehnk, M. D. (1990): Fundamentals of Investing. New York, HarperCollins, 1990.

[10] Kirpatrick, G. (2009): The Corporate Governance Lessons from the Financial Crises. [on-line], Paris, Organization for Economic Cooperation and Development, c2009, [cited $22^{\text {nd }}$ September, 2012], <http://www.oecd.org/finance/financialmarkets/42229620.pdf>.

[11] OECD (2012): Institutional Investors Assets, 2000-2008. [on-line], Paris, Organization for Economic Co-operation and Development, c2012, [cited 22. 9. 2012], $<\mathrm{http} / / /$ stats.oecd.org/Index.aspx?DatasetCode=7IA $>$.

[12] Private fund Investment Advisers Registration Act (2010). [on-line], Washington, D. C., U. S. Congress, c2010, [cited 21. 7. 2010], <http://www.compliancebuilding.com/wp-content/uploads/2010/08/P rivate-Fund-Investment-Advisers-Registration-Act-of-2010.pdf > .

[13] Revenda, Z. (2011): Centrální bankovnictví (Central Banking). Praha, Management Press, 2011.

[14] Sias, R. W. (1996): Volatility and the Institutional Investor. Financial Analysts Journal, 1996, vol. 52, no. 2, pp. 13-20.

[15] Directive 2011/61/EU of the European Parliament and of the Council of 8 June 2011 on Alternative Investment Funds Managers and amending Directives 2003/41/EC and 200/65/EC and Regulations (EC) No 1060/2009 and (EU) No 1095/2010. [on-line], Brussels, European Commission, c2011, [cited 8. 6. 2011], <http://eur-lex.europa.eu/LexUriServ/LexUriServ.do?uri=OJ:L:2011 :174:001:0073:CS:PDF>.

[16] Directive 2009/65/EC of the European Parliament and of the Council of 13 July 2009 on the coordination of laws, regulations and administrative provisions relating to undertakings for collective investment in transferable securities (UCITS). [on-line], Brussels, European Commission, 2009, [cited 13.7. 2009], <http://eur-lex.europa.eu/LexUriServ/LexUriServ.do?uri=OJ:L:2009 :302:0032:0096:cs:PDF>.

[17] TheCityUK (2012): Global Hedge Funds. [on-line], London, TheCityUK, c2012, [cited 29. 2. 2012], $<$ http://www.thecityuk.com/home/ZendSearchLuceneForm?Search= hedge+funds\&action_ZendSearchLuceneResults=Go>. 


\title{
Hedge Funds and their (Non)regulation
}

\author{
Petr MUSÍLEK
}

\begin{abstract}
The objective of this contribution is not only to explain the position of institutional investors on global capital markets, but also evaluate their impact on the operation of financial systems. The core of this contribution is dedicated to hedge funds that in the period before the outbreak of global financial crisis were not subjected to almost any regulation, except for some dishonest practices. Institutional response to the global financial crisis however changed significantly the regulatory-supervisory approach also to hedge funds. The Dodd-Frank Act introduced quite promptly sensitive registration of important investment managers of hedge funds in the USA. At the same time, the new American financial legislation passed the duty for managers of hedge funds and other private funds to keep prescribed records. On the other hand, the European directive on managers of alternative investment funds has a very restrictive nature, because it implements a standard license system, costly internal and external control mechanisms, and increases inadequately powers of supervisory authorities.
\end{abstract}

Key words: Institutional investors; Hedge funds; Alternative investment funds managers; Regulation and supervision; Global financial crisis.

JEL classification: G230. 